\title{
MATEMATIKA MEMAHAMI TRIPEL PYTHAGORAS: SUATU TINJAUAN SEJARAH MATEMATIKA DARI ZAMAN PYTHAGORAS, PLATO, DAN EUCLID
}

\author{
Ikhbariaty Kautsar Qadry', Syahrullah Asyari², Muhammad Darwis M', \\ Sahlan Sidjara ${ }^{4}$ \\ ${ }^{1 *}$ Universitas Muhammadiyah Makassar, Makassar Indonesia \\ 2,3,4Jurusan Matematika, FMIP Universitas Negeri Makassar, Makassar, Indonesia \\ Email: ikhbariaty.qadry@unismuh.ac.id
}

\begin{abstract}
Abstrak:
Pandemi covid 19 yang melanda semenjak bulan Maret 2020 hingga saat ini sangat Tripel Pythagoras adalah bagian dari konsep Teorema Pythagoras yang tak terpisahkan dari fondasi untuk menyelesaikan masalah praktis geometri. Pengetahuan dan pemahaman yang memadai yang dimiliki oleh seorang guru matematika tentang suatu konsep, seperti Tripel Pythagoras, juga berkontribusi bagi pengetahuan dan pemahaman siswa. Pengetahuan dan pemahaman yang memadai tersebut dapat dibentuk melalui pemahaman terhadap suatu konsep tertentu secara historis. Studi di beberapa negara maju maupun berkembang menunjukkan rendahnya pengetahuan guru matematika tentang sejarah matematika. Workshop Tripel Pythagoras adalah suatu langkah alternatif membekali guru matematika dengan pengetahuan dan pemahaman yang memadai tentang Tripel Pythagoras secara historis. Tiga aktivitas utama workshop ini adalah demonstrasi pengetahuan atau skill, pemberian praktik terbimbing, dan pemberian umpan balik. Hasil penilaian formatif dan evaluasi diri peserta menunjukkan bahwa peserta workshop secara individu telah memiliki pengetahuan dan pemahaman yang memadai tentang Tripel Pythagoras secara historis.
\end{abstract}

Kata Kunci: Sejarah Matematika, Tripel Pythagoras, Plato, Euclid.

\section{Pendahuluan}

Sejarah matematika memainkan peran signifikan bagi keberhasilan kelas matematika. Setidaknya karena sebagaimana yang dikemukakan oleh Lucia Grugnetti, seorang peneliti sejarah matematika dalam pembelajaran, bahwa “... students presented with a historical context have the opportunity to evaluate their own problem-solving strategies, while the teacher may gain insight into the source of student difficulties." (Deakin, 2001). Menurut Grugnetti, siswa yang mempelajari matematika dengan konteks sejarah berkesempatan untuk mengevaluasi strategi pemecahan masalah mereka sendiri, sementara itu guru memperoleh pengetahuan dan wawasan tentang sumber kesulitan siswa dalam mempelajari suatu konsep. 
Tripel Pythagoras adalah suatu konsep yang terkadang dipandang sebelah mata oleh sebagian pendidik matematika. Padahal ini dapat melatih siswa berpikir kritis dan kreatif melalui investigasi keterkaitan antar bilangan bulat positif dengan segitiga siku-siku. Terlebih lagi, bila materi ini disajikan dalam konteks sejarah, siswa dilatih mengevaluasi strategi pemecahan masalah mereka sendiri, sebagaimana dikatakan oleh Grugnetti. Pemahaman yang baik tentang Tripel Pythagoras akan memudahkan siswa memahami segitiga siku-siku. Kita pun mengetahui bahwa segitiga siku-siku adalah fondasi trigonometri. Adapun trigonometri itu sendiri telah dianggap sebagai problem solver atas masalah praktis geometri (Abbott, 1992). Ini berarti bahwa pemahaman terhadap Tripel Pythagoras pada dasarnya adalah suatu fondasi untuk menyelesaikan masalah praktis geometri.

Dalam upaya memahami Tripel Pythagoras tersebut, siswa membutuhkan guru sebagai fasilitator. Pengetahuan dan pemahaman guru berkontribusi bagi pengetahuan dan pemahaman siswa. Ini berarti bahwa pengetahuan dan pemahaman guru tentang Tripel Pythagoras juga berkontribusi bagi bentuk Tripel Pythagoras yang diterima oleh siswa. Dengan demikian, dapat dikatakan bahwa pemahaman guru tentang Tripel Pythagoras penting menjadi perhatian para peneliti dan pemerhati pendidikan matematika.

Hasil studi dari berbagai negara menunjukkan bahwa calon guru matematika tidak memiliki pengetahuan dan wawasan yang memadai tentang hakikat matematika dan aktivitas matematika (Alpaslan et al, 2014). Hakikat dan aktivitas matematika yang dimaksud di sini adalah sejarah matematika. Alpaslan et al (2014) juga menyebutkan hasil penelitian dari beberapa negara, seperti Itali, Amerika Serikat, Zimbabwe, dan Turki, menunjukkan bahwa calon guru matematika di negara-negara tersebut tidak memiliki pengetahuan dan wawasan yang memadai tentang sejarah matematika.

Lalu, bagaimana dengan Indonesia? Kami belum pernah mendapatkan laporan studi yang menelusuri penggunaan sejarah dalam mengajarkan matematika di Indonesia. Tapi, kami bisa berhipotesis bahwa kondisi di Indonesia lebih memprihatinkan dari negara-negara tersebut dengan melihat eksistensi matakuliah sejarah matematika di perguruan tinggi di Indonesia, khususnya Sulawesi Selatan. Matakuliah sejarah matematika ada dalam kurikulum Pendidikan Matematika Universitas Negeri Makassar, meskipun masih berstatus pilihan. Sementara itu, pada perguruan tinggi lain, matakuliah sejarah matematika bahkan tidak ada dalam kurikulum Program Studi Pendidikan Matematika mereka. Mungkin saja ada alasan rasional di balik tidak adanya matakuliah sejarah matematika tersebut. Tetapi, menurut hemat 
kami sejauh ini, hal ini menunjukkan bahwa perhatian terhadap sejarah matematika dan urgensinya dalam pembelajaran matematika di sekolah masih kurang.

Sebuah mini research pernah kami lakukan untuk menelusuri eksistensi sejarah matematika dalam pengalaman pendidikan para guru matematika. Dari beberapa guru alumni Program Diploma II dan III Pendidikan Matematika IKIP Ujung Pandang diketahui bahwa mereka pernah mendapatkan pengalaman belajar sejarah matematika saat kuliah. Tetapi, pengalaman tersebut tidak cukup memadai membentuk pemahaman mereka tentang, misalnya, Tripel Pythagoras, maupun pada konsep matematika yang lain secara historis. Terlebih lagi, Teorema Pythagoras yang ada di Kurikulum 2013 masih bersifat umum. Maksudnya, tidak ada penekanan pada adanya bentuk khusus berupa tripel Pythagoras. Hal ini menguatkan pentingnya diadakan suatu kegiatan yang dapat membekali guru matematika dengan pengetahuan dan pemahaman yang memadai tentang konsep Tripel Pythagoras.

\section{Metode Pelaksanaan}

Berdasarkan uraian di atas, diketahui bahwa para guru membutuhkan penyegaran (refreshing) materi Tripel Pythagoras berdasarkan tinjauan sejarah matematika. Sebagai upaya menyelesaikan masalah tersebut, ditawarkan metode workshop yang diberi nama Workshop Tripel Pythagoras. Adapun prosedur kerja pada metode ini sebenarnya adalah adaptasi dari model Direct Instruction dalam pembelajaran oleh Arends (2012).

1) Prosedur Kerja

Untuk mendukung realisasi metode yang ditawarkan, prosedur kerja metode ini adalah: (a) Penyampaian tujuan dan pemberian motivasi kepada peserta, (b) Demonstrasi pengetahuan dan/atau skill kepada peserta, (c) Pemberian praktik terbimbing (guided practice) kepada peserta di depan kelas, (d) Pemberian umpan balik (feedback) atau interaktif narasumberpeserta, dan (e) Pengecekan pemahaman peserta (Evaluation) terhadap materi.

2) Deskripsi Kegiatan

Kegiatan ini diikuti oleh 16 orang guru dari 4 SMP negeri berbeda di Kabupaten Takalar, Propinsi Sulawesi Selatan. Kegiatan ini hanya berlangsung satu pertemuan dalam durasi 4 (empat) jam. Secara umum, kegiatan ini dibagi menjadi dua bagian. Pertama, penyampaian konsep Tripel Pythagoras berdasarkan tinjauan sejarah matematika. Kedua, praktik menyelesaikan soal, umpan balik, dan kesimpulan materi.

Secara detail, deskripsi kegiatan dalam penyegaran materi Tripel Pythagoras berdasarkan tinjauan sejarah matematika dapat diuraikan sebagai berikut. 
Tabel 1 Deskripsi Kegiatan

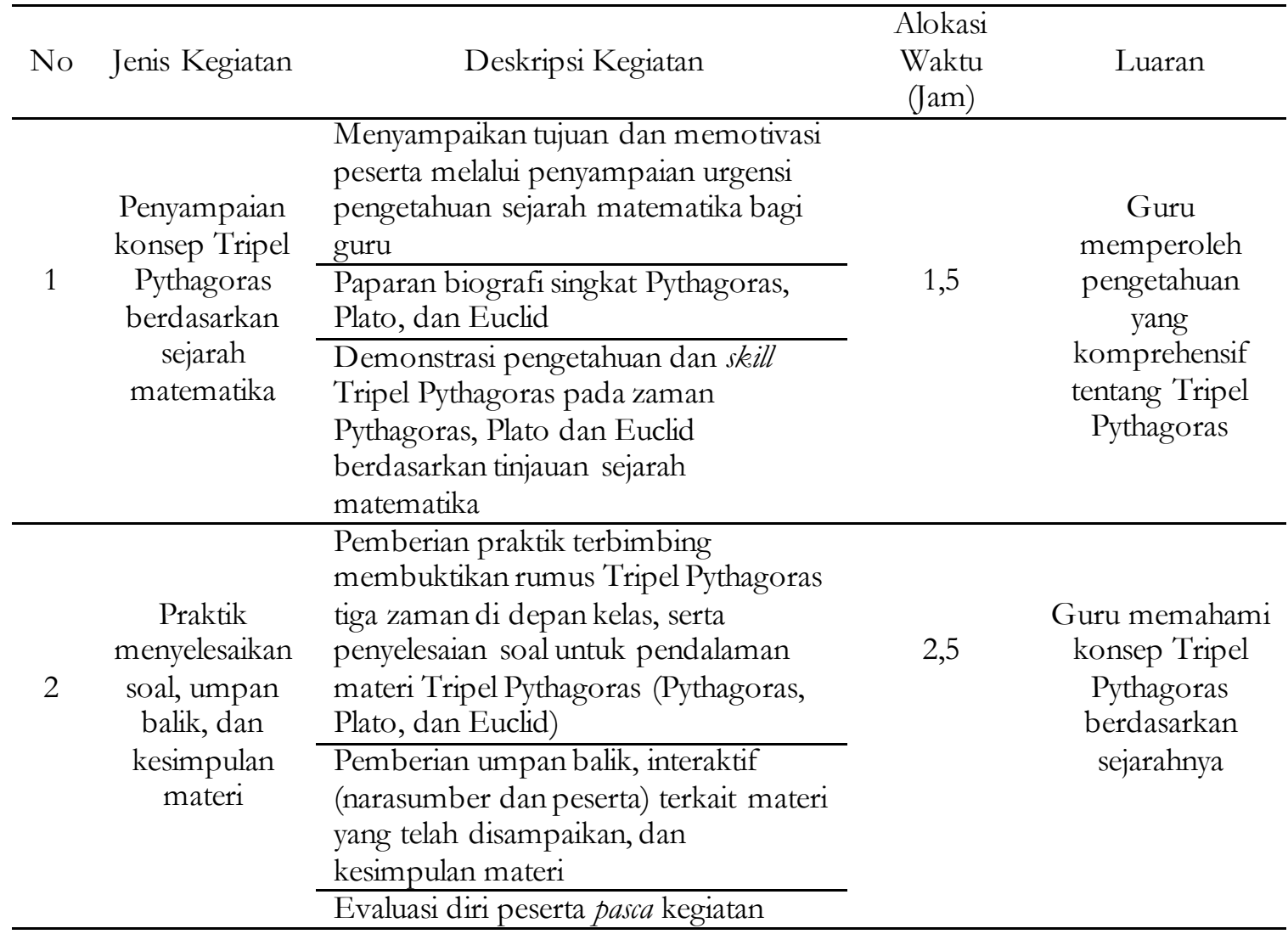

\section{Hasil dan Pembahasan}

Kegiatan ini adalah Workshop Tripel Pythagoras. Kegiatan ini dilaksanakan selama sekitar 4 (empat) jam, mulai Pkl. 09.00 - 13.00 wita. Materi Tripel Pythagoras yang ditampilkan dalam workshop ini mengacu pada "The History of Mathematics: An Introduction 7th Edition" oleh Burton (2007). Salah satu bab dalam buku ini membahas tentang "Permasalahan Kaum Pythagoras". Tripel Pythagoras adalah salah satu di antara Permasalahan Kaum Pythagoras yang dibahas dalam buku itu. Burton (2007) memaparkan Solusi Awal Persamaan Pythagoras berdasarkan tiga zaman, yaitu Pythagoras sendiri, Plato, dan Euclid.

Tripel $(x, y, z)$ dari bilangan bulat positif yang memenuhi persamaan $x^{2}+y^{2}=z^{2}$ ini dikatakan sebagai Tripel Pythagoras. Pada zaman Pythagoras sendiri, nilai Tripel $(x, y, z)$ tersebut diperoleh dengan rumus: $x=2 n+1, y=2 n^{2}+2 n, z=2 n^{2}+$ $2 n+1$, di mana $n \geq 1$. Pada zaman Plato, rumus tripel tersebut berkembang menjadi: $x=$ 
$2 n, y=n^{2}-1, z=n^{2}+1$, di mana $n>1$. Perkembangan rumus tripel berikutnya adalah pada masa Euclid. Euclid-lah yang menulis solusi lengkap untuk permasalahan Pythagoras, termasuk tripel Pythagoras, yaitu pada buku X dari seri Elements, $x=2 m n, y=m^{2}-n^{2}$, $z=m^{2}+n^{2}$, di mana $\mathrm{m}$ dan $\mathrm{n}$ adalah bilangan-bilangan bulat positif dengan $m>n$.

\section{Pythagoras}

Pada zaman Pythagoras sendiri, nilai Tripel $(x, y, z)$ diperoleh dengan rumus: $x=$ $2 n+1, \quad y=2 n^{2}+2 n, \quad z=2 n^{2}+2 n+1$, di mana $n \geq 1$. Dalam workshop ini, guru dibimbing untuk menunjukkan tripel Pythagoras pada zaman Pythagoras. Berikut ini adalah gambar aktivitas tersebut.

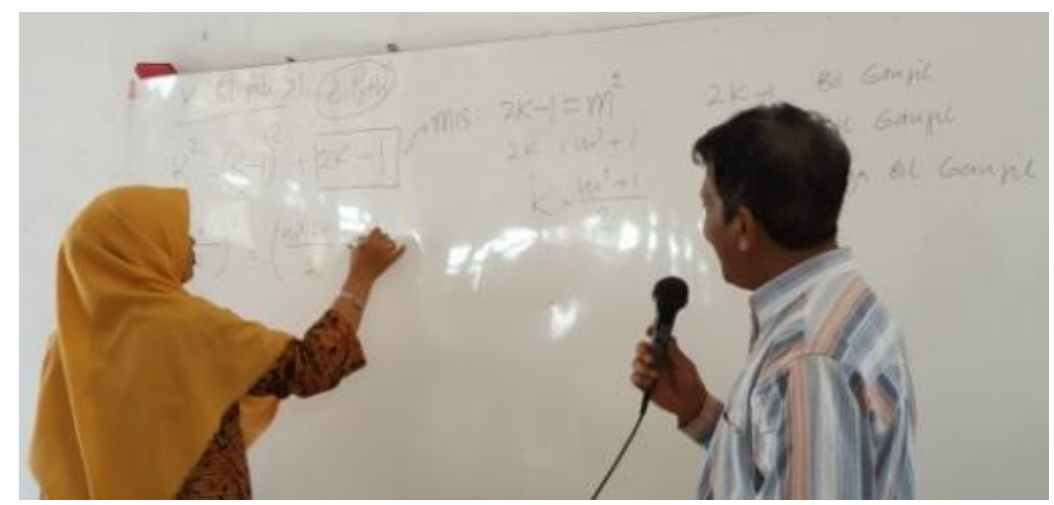

Gambar 1 :Guru Dibimbing Menunjukkan Rumus Tripel Pythagoras pada Zaman Pythagoras

\section{Plato}

Pada zaman Plato, rumus tripel tersebut berkembang menjadi: $x=2 n, y=n^{2}-1$, $z=n^{2}+1$, di mana $n>1$. Dalam workshop ini, guru juga dibimbing untuk menunjukkan tripel Pythagoras pada zaman Plato. Berikut ini adalah gambar aktivitas tersebut.

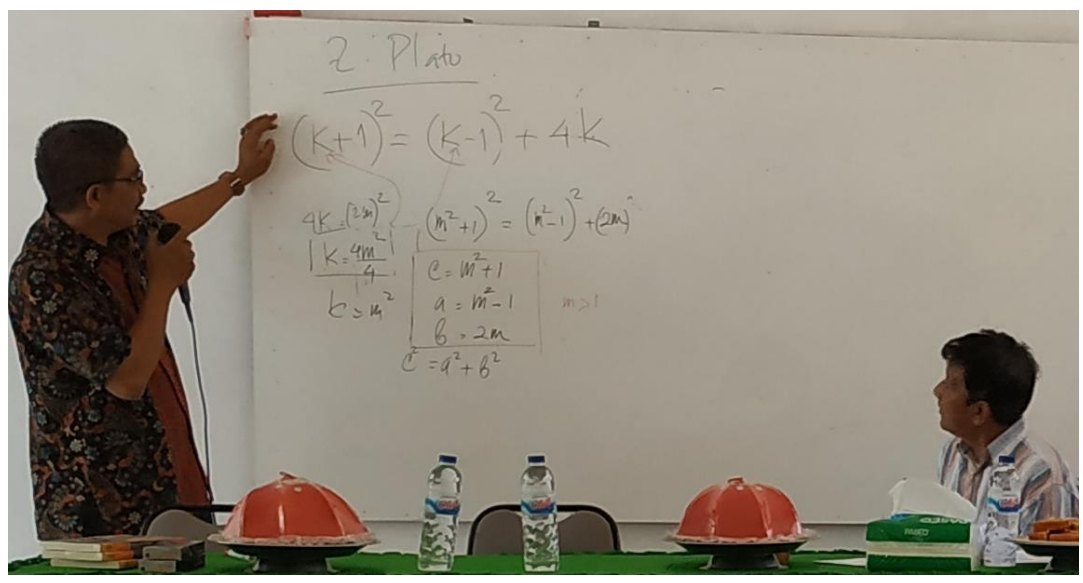

Gambar 2: Guru Dibimbing Menunjukkan Rumus Tripel Pythagoras pada Zaman Plato 


\section{Euclid}

Pada zaman Euclid, rumus tripel tersebut berkembang menjadi: $x=2 m n, y=m^{2}-$ $n^{2}, z=m^{2}+n^{2}$, di mana $\mathrm{m}$ dan $\mathrm{n}$ adalah bilangan-bilangan bulat positif dengan $m>n$. Dalam workshop ini, guru juga dibimbing untuk menunjukkan tripel Pythagoras pada zaman Euclid. Berikut ini adalah gambar aktivitas tersebut.

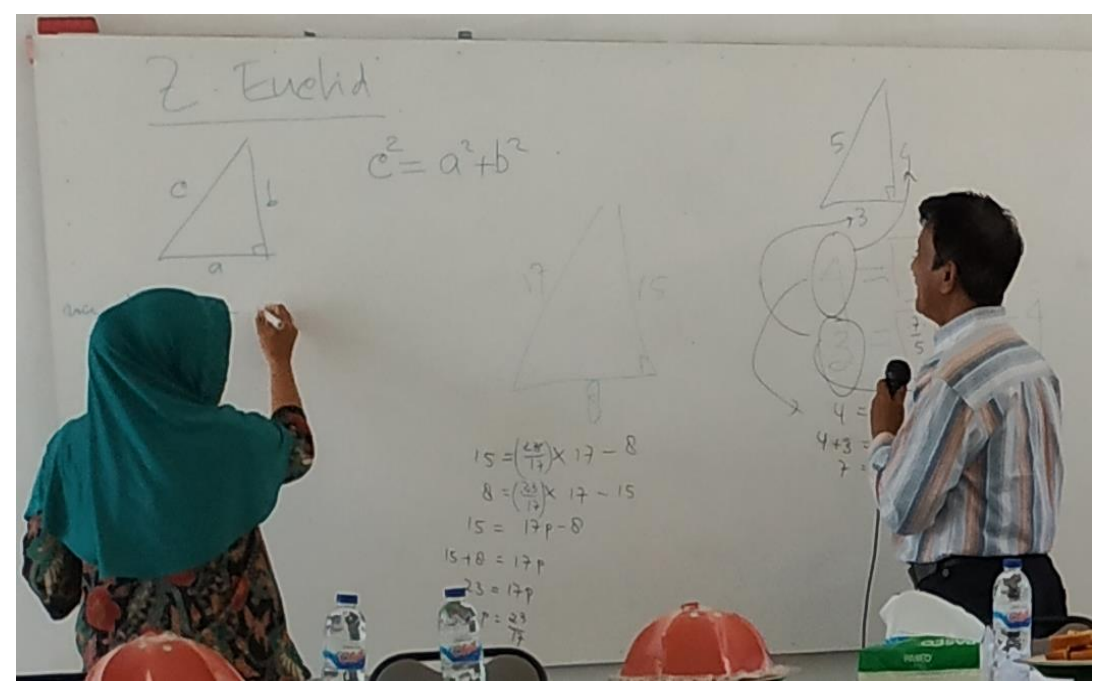

Gambar 3: Guru Dibimbing Menunjukkan Rumus Tripel Pythagoras pada Zaman Euclid

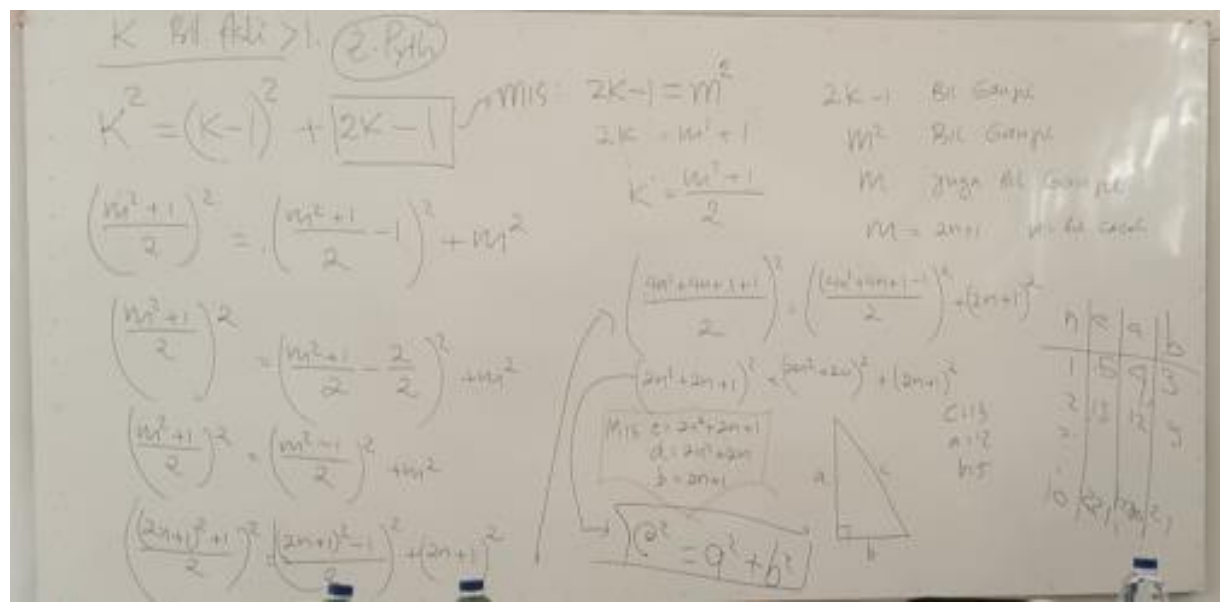

Gambar 4: Contoh Hasil Kerja Guru Menunjukkan Rumus Tripel Pythagoras 
Luaran yang dicapai melalui kegiatan ini secara umum adalah guru matematika memiliki kompetensi keilmuan tentang Tripel Pythagoras. Secara spesifik, luaran yang dicapai, yaitu: guru mengenal Pythagoras, guru mengetahui perkembangan tripel pythagoras di tiga zaman, guru mampu menjelaskan tripel Pythagoras secara matematis sesuai zaman perkembangannya, dan guru memiliki pemahaman yang utuh tentang tripel Pythagoras

\section{Kesimpulan}

Inti pelaksanaan kegiatan ini adalah Workshop Tripel Pythagoras. Kegiatan ini telah menyadarkan guru matematika akan pentingnya sejarah matematika. Kegiatan ini menambah pengetahuan dan memperluas wawasan guru tentang Tripel Pythagoras secara historis konseptual yang akan berkontribusi bagi keberhasilan kelas matematika. Adanya bekal kemampuan ini, para guru diharapkan menyajikan materi tripel pythagoras secara lebih kreatif dan menyenangkan bagi siswa, karena guru telah memahami konsepnya sesuai tinjauan historis. Berdasarkan uraian dapat disarankan sebagai berikut:

a. Pengembangan buku sejarah matematika sebagai bahan bacaan dan kajian bagi guru matematika untuk mendukung pengembangan kompetensi keilmuan mereka

b. Penyelenggaraan workshop bagi guru matematika menyebarluaskan pemaknaan setiap konsep matematika secara historis

\section{Referensi}

Abbott, P. 1992. Teach Yourself Trigonometry. Chicago: NTC/Contemporary Publishing Company.

Alpaslan, M., Işıksal, M., \& Haser, Ç. (2014). Pre-service mathematics teachers' knowledge of history of mathematics and their attitudes and beliefs towards using history of mathematics in mathematics education. Science \& Education, 23(1), 159-183.

Arends, R. I. 2012. Learning to Teach (Ninth Edition). New York: McGraw-Hil Companies, Inc.

Burton, D. M. 2007. The History of Mathematics: An Introduction (Seventh Edition). New York: McGraw-Hil Companies, Inc.

Deakin, M. A. B. 2001. Katz, Victor (Ed.) Using History to teach Mathematics: An International Perspective. ZDM, 33 (5), 137-138. 